\title{
Firm size and supply chain finance in Indian pharmaceutical industry: Relational firm analysis of size determinants and cash conversion cycle
}

\author{
Anis Ali ${ }^{*}$
}

${ }^{a}$ Department of Management, College of Business Administration, Prince Sattam Bin Abdulaziz University, Al kharj- 11942, Saudi Arabia

\begin{tabular}{l}
\hline C H R O N I C L E \\
\hline Article history: \\
Received: April 28, 2020 \\
Received in revised format: \\
July 30 2020 \\
Accepted: September 25, 2020 \\
Available online: \\
September 25, 2020 \\
\hline Keywords: \\
Cash conversion cycle \\
Supply chain finance \\
Size determinants \\
Working Capital \\
Saudi Arabia
\end{tabular}

\begin{abstract}
A B S T R A C T
The sales revenue, total resources, and Working Capital (WC) of the business organization measure the size of the firms. The Cash Conversion Cycle (CCC) defines the Supply Chain Finance (SCF) of the business organization and is affected by the size determinants of the firms. The components of the WC are considered to measure the CCC and define the status of the SCF of the business organization. The study is based on the secondary data obtained from the financial statements of the selected leading Indian pharmaceutical companies. The objective of the study is to find out the relation and degree of governance of size determinants on the SCF. The analysis is based on the ranks of size determinants and relative ranks of inventory days, accounts receivables days, and accounts payables days. The Spearman rank correlation is applied to get the qualitative relationship between the ranks of size determinants and ranks of components of CCC. The study reveals that size determinants affect the SCF positively but moderately while WC governs directly as WC comprises the components of CCC. The study suggests the shortening of the CCC by focusing on size determinants on WC and especially accounts payables in Indian pharmaceutical companies.
\end{abstract}

(C) 2021 by the authors; licensee Growing Science, Canada

\section{Introduction}

The size of firms governs the absolute financial performances of the business organization positively while there is a negative relationship seen in the efficiency of financial performance as the size of the firm enhances (Ali, 2020b). The size of the firm positively but moderately governs the solvency of the Indian pharmaceutical firms (Ali, 2020c). Normally, the size of a firm is measured by applying the three approaches i.e. level of activities, total resources, and available funds to run the operational activities of the business organization. Hence, sales revenue, total assets, and working capital are to be used as proxy to measure the size of the firm (Ali, 2020a). Supply Chain Finance (SCF) refers to the fund needed to run the operational Cycle or Cash Conversion Cycle (CCC) in a business organization (Chand et al., 2020). The CCC of a business organization is a systematic process that starts from the introduction of cash to start the production or service rendering process and ends with the collection from the customers or accounts receivables and payment to the suppliers and accounts payables and ultimately procures cash for the next operational cycle. Keown et al. (2003) explained that the CCC is the sum of the average collection period (days) and days involved in sales of inventory of finished products minus numbers of days to make payment to the account payables. Hence, $\mathrm{CCC}$ is a continuous process of the sale of inventory of finished products, collection from the account receivables, and payment to the accounts payables and measured in the number of days, normally (Balasubramanian et al., 2020).

* Corresponding author

E-mail address: ah.ali@psau.edu.sa (A. Ali) 


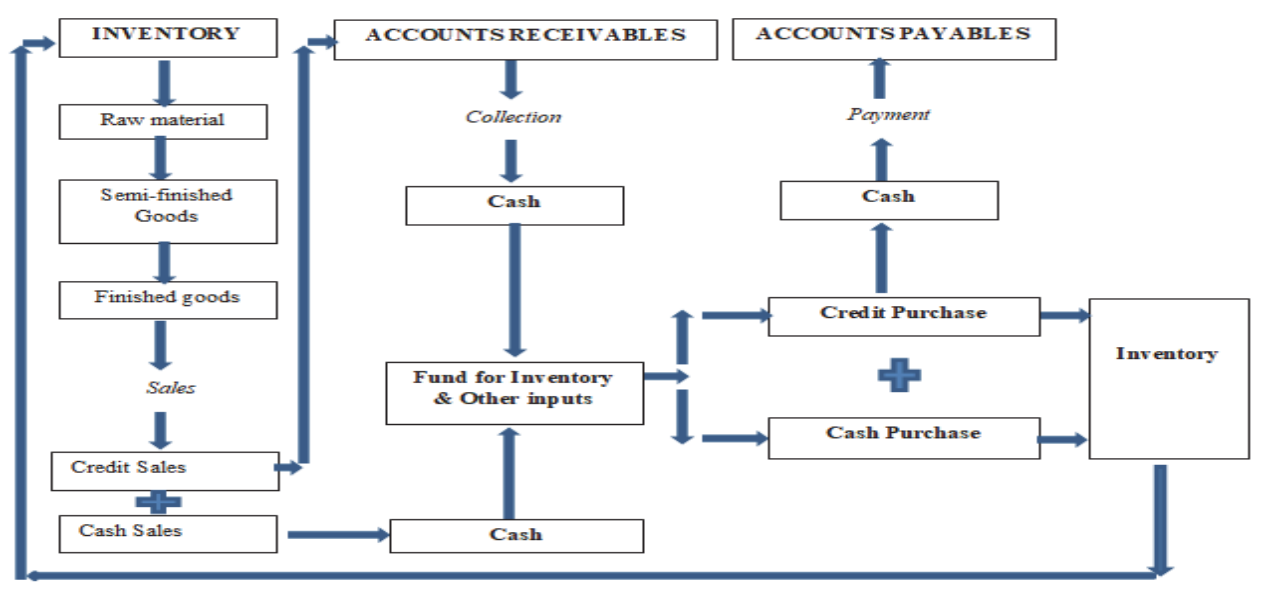

Source: Author's formation based on the process of CCC

Fig. 1. Process of Cash Conversion Cycle (CCC)

From Fig. 1, it is obvious that there are components of the WC i.e. inventory, accounts receivables, and accounts payables involved in the process of CCC. The CCC is explained as a span of time or days that are necessary to complete an operational cycle of the business organization. The CCC is measured by inventory, accounts receivables, and accounts payables that are the components of the Working Capital (WC) while WC is one of the size determinants of the firm. So, the level or change in the level of the WC affects the CCC. WC is the subset of the Total Assets (TA) and governs the level of activities of the business or sales revenue. So, the three size determinants of the business govern the CCC or the SCF as the CCC is the technique to measure the SCF (Bui, 2020c; Lin \& Lin, 2020; Zhou \& Li, 2020). The size determinants (TA, WC, and sales revenue) of the Indian pharmaceutical companies enhance progressively.

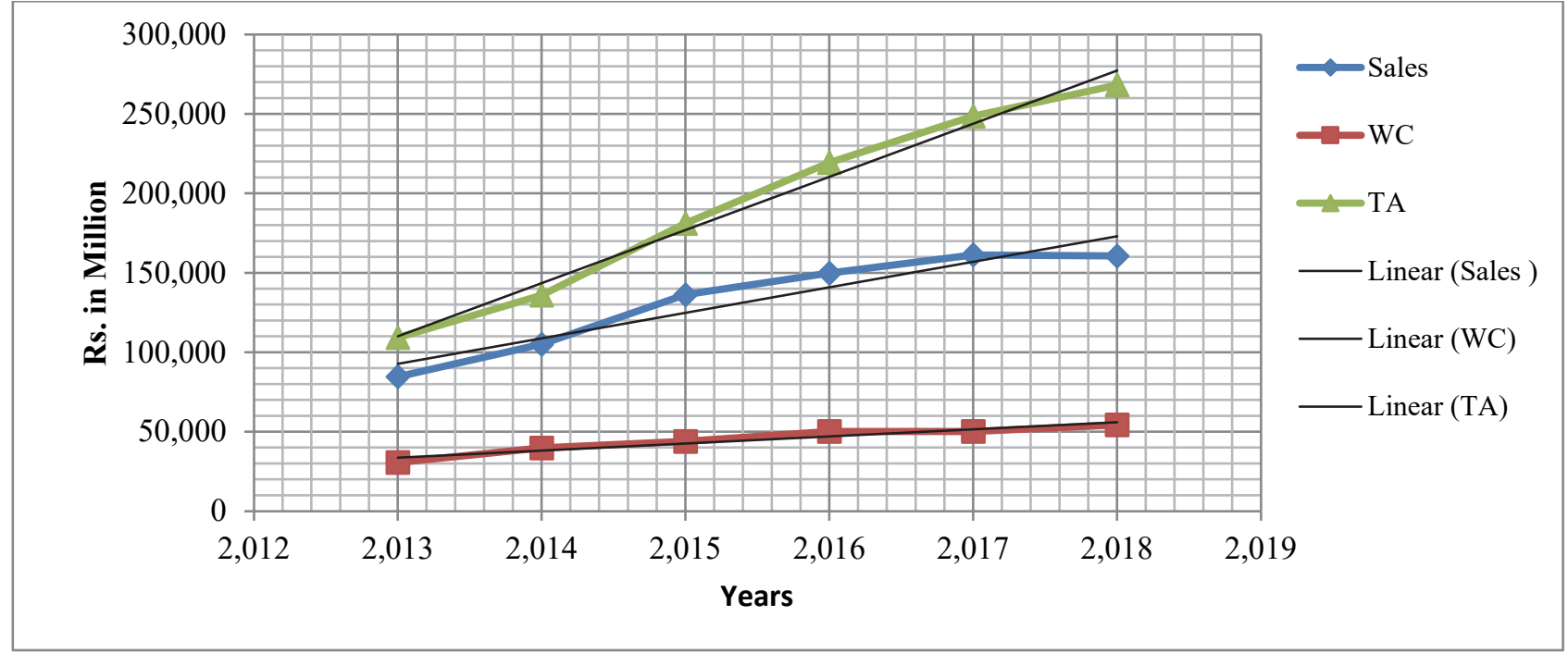

Source: Average amounts of size determinants calculated from the financial statements of selected leading pharmaceutical companies

Fig. 2. Growth trend of Size determinants of Selected Ind. Pharmaceutical Companies

Fig. 2 explains the growing trend of the firm size determinants and reveals that the growth rate of the TA leads to the growth rate of sales revenue and WC. So, it is assumed that the TA governs strongly the CCC than WC and sales revenue. Hence, there is a need to find out the size determinants and their relative degree to govern the SCF in Indian pharmaceutical companies. There are very few studies available that explain the relationship of size determinants and CCC applying the three proxies of size i.e. TA, WC, and sales revenue. The outcomes of the study expected to facilitate the entrepreneurs, supply chain managers, and finance managers in-depth insights into CCC to minimize the level of SCF by shortening the CCC period in the Indian pharmaceutical sector. 


\section{Literature Review}

\subsection{Supply chain management practices, Supply chain intelligence, and Supply chain performance}

Phan et al. (2020) studied the relationship between Supply Chain Management Practices (SCMP) and Supply Chain Performance (SCP) in the textile industry in Vietnam and found that Supply Chain Intelligence (SCI) plays an intermediary role in between SCMP and SCP. The researchers found that the SCMP contributes to the effectiveness of SCM globally.

\subsection{Cash conversion cycle, Profitability, Financial development, Size, economic growth, and supply chain performance}

Bui (2020a) carried out a study between financial development and profitability and found that SCP and financial development plays a vital role in the enhancement of profitability. The profitability of real estate firms positively correlated with financial development while negatively with the CCC. The profitability of the firm positively correlated with the size of the firm. Bui and Doan (2020) found the negative relationship between the size of the firm, Financial Leverage (FL), Return on Assets (ROA), and GDP on the SCP. Wagner et al. (2012) found a positive relationship between the ROA and supply chain efficiency.

\subsection{Financial Leverage, Firm performance, Supply chain finance, and Cash conversion cycle}

Bui (2020b) studied that the FL and SCF affect the performance of the construction firms in Vietnam. However, FL is more influential than SCP in the enhancement of firms' performance. Doan and Bui (2020) found a negative relationship between firm performance and CCC. Firms' performance effected by internal factors i.e. Size of the firm, Capital structure, and external factors i.e. macroeconomic factors and economic growth.

2.4 Size, investment, Resource, Organizational performance, Cash Conversion Cycle, Capital Structure, and Supply Chain Finance

Mani et al. (2020) conducted a study between supply chain social responsibility and SCP in SMEs and found a positive relationship. Operational performance (OP), Customers' Performance (CP), suppliers' performance (SP), and supply chain performance (SCP) were determined by the size of the firm and investment. Cho et al. (2019) advocated the importance of supply chain finance (SCF) in the utilization of the resources. Younis and Sundarakani (2019) found a negative relationship between the size of the firm and the operational performance of the business while positivity between economic, environmental, and social performance. Bui (2020c) explained that the CCC measures Supply chain Finance (SCF). The corporate performance is negatively affected by the CCC while positively by the SCF implied that the higher CCC reflects the lower SCF. The SCF is also governed by the capital structure, a firm's growth, and the size of the firm.

\subsection{Inventory Management, Accounts Receivables, Accounts Payables and Supply Chain Performance, Cash Conversion Cycle}

Upadhyay and Smith (2020) explained that the inventory management affects the CCC of the hospitals and advocated the optimal level of the inventory for uninterrupted activities. Wang et al. (2020) explained that the size and status of the firm affect the inventory performance of the business organization. Gelsomino et al. (2016) bifurcated the concept of the SCF into two categories i.e. finance-oriented and supply chain oriented. The finance-oriented concept considers the short-term solutions by the financial institutions and accounts receivables, payables while the supply chain oriented concept considers the optimization of WC by the accounts receivables, accounts payables, and fixed assets financing.

\subsection{Supply chain performance, Cash conversion cycle and other factors}

Panayides and Lun (2009) found a positive relationship between SCP and trust while the historical performance governs the trust of the customers. Whitten et al. (2012) found that triple-A supply chain strategy (agility, adaptability, and alignment) affects the SCP positively and indicated that the SCP is strongly governed by the marketing performance than financial performance. Also, marketing performance governs the financial performance of the business organization. Sundram et al. (2011) explained that the SCP is positively governed by the SCMP. Hsin Chang et al. (2013) indicated that e-procurement enhances the SCP while the partnership relationship, supply chain integration, and information sharing represent e-procurement.

\section{Materials and Methods}

The study of the relationship of firms' size determinants and SCF is based on the secondary data taken from the websites of the Indian pharmaceutical companies. Sun Pharmaceutical Industries Limited (SU), Cipla Limited (CI), Cadila Healthcare Limited (CA), Aurobindo Pharma Limited (AR), Dr. Reddy's Laboratories (DR), and Lupin limited (LU), Glenmark Pharma Limited (GL) pharmaceutical companies selected for the study of the relationship of firm's size determinants and solvency or financial soundness. Bui (2020c) explained that the CCC measures the SCF while Gelsomino et al. (2016) bifurcated the concept of the 
SCF into two categories i.e. finance-oriented and supply chain oriented. The finance-oriented concept considers the short-term solutions by the financial institutions and accounts receivables, payables. The supply chain oriented (Chen et al., 2020; Maeenuddina et al., 2020) concept considers the optimization of working capital (WC) by the accounts receivables, accounts payables, and fixed assets financing. As per Mani et al. (2020), supply chain performance is governed by the size of the firm positively while Bui and Doan (2020) discovered a negative relationship. Ali (2020b) applied three proxies to determine the financial size of the firms' i.e. total assets (TA), sales revenue, and WC. To find out the relationship between the size determinants of the firm and SCF, the following model can be applied.

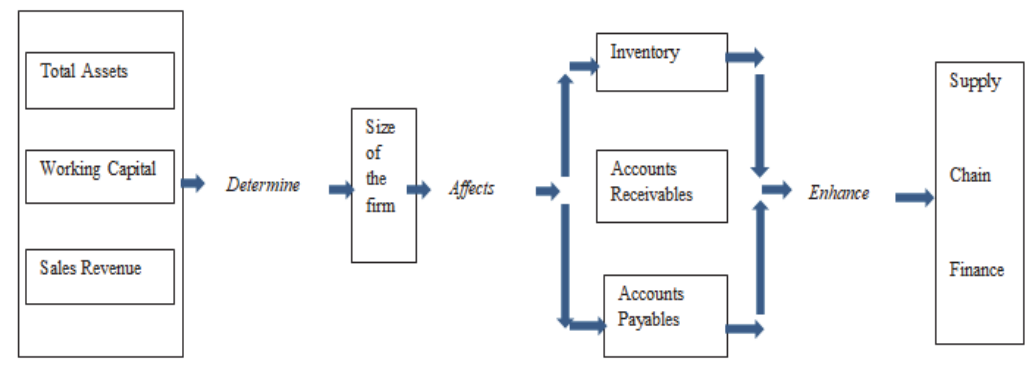

Source: Proposed by author

Fig. 3. Suggested research model

The analysis of the study applies the various variables of the financial statements of Indian pharmaceutical companies to establish the relational co-movement of the size determinants and CCC days to get the impact of firms' size determinants on $\mathrm{SCF}$ as the SCF is measured by the CCC.

\section{Table 1}

Data description and sources

\begin{tabular}{lllll}
\hline Variables & Descriptions & Sources & Variables & Descriptions \\
\hline Net Sales & Sale of Indian pharmaceutical products & Financial statements & CL & Current Liabilities \\
TA & Total assets & Financial statements & Ac-R & Account Receivables \\
WC & Working capital (CA-CL) & Financial statements & Ac-P & Financcount payables \\
CA & Current assets & Financial statements & Inv. & Inventory/ stock \\
\hline
\end{tabular}

The average absolute amounts from the financial statements used to determine the size of the Indian pharmaceutical companies, relatively. The average ranks of three proxies i.e. TA, WC, and sales revenue are to be used to determine the size of the selected Indian pharmaceutical companies. Ac- R, Ac- P, and inventory are used to calculate the receivable days, payable days, and inventory days to get the days of CCC, ultimately.

\section{Table 2}

Size \& Rankings of the selected leading Indian pharmaceutical companies (2013-18)

\begin{tabular}{|c|c|c|c|c|c|c|c|}
\hline \multirow[b]{2}{*}{ Size Determinants } & \multicolumn{6}{|c|}{ Indian pharmaceutical companies } & \multirow{2}{*}{$\frac{\text { (Rs. in Million) }}{\text { GL }}$} \\
\hline & SU & $\mathrm{LU}$ & DR & $\mathrm{CI}$ & $\mathrm{AR}$ & $\mathrm{CA}$ & \\
\hline TA & 464474 & 179864 & 187476 & 176201 & 137885 & 112850 & 97422 \\
\hline R1 & 1 & 3 & 2 & 4 & 5 & 6 & 7 \\
\hline WC & 130960 & 55724 & 37184 & 41462 & 21521 & 7593 & 19358 \\
\hline $\mathrm{R} 2$ & 1 & 2 & 4 & 3 & 5 & 7 & 6 \\
\hline Sales & 241128 & 137190 & 142354 & 126912 & 120157 & 90097 & 72660 \\
\hline R3 & 1 & 3 & 2 & 4 & 5 & 6 & 7 \\
\hline Av. of Ranks & 1 & 2.67 & 2.67 & 3.67 & 5 & 6.33 & 6.67 \\
\hline Composite ranks of Size Determinants & 1 & 2.5 & 2.5 & 4 & 5 & 6 & 7 \\
\hline
\end{tabular}

Source: Average absolute amounts of TA, WC, and sales are taken from the financial statements of the concerned companies for the period 2013-18.

Table 2 explains the size of the Indian pharmaceutical companies as per the size determinants i.e. TA, WC, and sales. As per table 2, Sun Pharmaceutical Industries Limited (SU), Dr. Reddy's Laboratories (DR), Lupin limited (LU), holds the first, second, third position while Cipla Limited (CI), Aurobindo Pharma Limited (AR), Cadila Healthcare Limited (CA), Glenmark Pharma Limited (GL) hold the fourth, fifth, sixth, and seventh position in the selected pharmaceutical companies. The cash conversion cycle (CCC) calculated to know the performance of SCF efficiency or operational velocity of Indian pharmaceutical companies.

$\mathrm{CCC}=$ Inventory Days + Accounts Receivable Days - Accounts Payable Days;

where, 
Inventory days $=\frac{365 * A v \cdot I n v .}{\text { COGS or Net Sales }} ;$ Account Receivable days $=\frac{\text { A. Ali } / \text { Accounting } 7(2021)}{\text { Credit Sales or Net Sales }} ;$ Account Payable days $=\frac{365 * A v . A c-P}{\text { COGS or Net Sales }}$

(Note: In the above formula, Net sales can be used in place of COGS while COGS is Cost of Goods Sold.)

Spearman's rank correlation is calculated to get the relative correlation between size determinants and components of the CCC days.

Spearman's Rank Correlation $\left(\mathrm{r}_{\mathrm{s}}\right)=1-\frac{6 * \sum(D * D)}{n(n * n-1)}$

\section{Analysis, results and interpretations}

To achieve the objectives of the research the analysis can be divided between two broad categories i.e. CCC analysis and relational co-movement of the size determinants (TA, sales revenue, and WC) and components of CCC (Inventory days, Receivables days, and payables days).

\subsection{Cash Conversion Cycle (CCC) analysis}

The CCC analysis considers the process of the conversion of cash into cash after the completion of a normal course of business activities of the production process, collecting revenue from the customers or receivables and payment to suppliers or the accounts payables. The CCC analysis can be measured by adding the inventory days and accounts receivables days and subtracting the accounts payables days.

\subsection{Inventory Days}

In the calculation of $\mathrm{CCC}$, inventory days refer to the days of production process or days of conversion of raw material into finished products. The lower inventory days refer to the manufacturing or production efficiency of the business organization.

Table 3

Inventory days in Indian Pharmaceuticals Companies (2013-18)

\begin{tabular}{|c|c|c|c|c|c|c|c|}
\hline Years & DR & LU & SU & CI & $\mathrm{AR}$ & $\mathrm{CA}$ & GL \\
\hline 2013 & 134 & 73 & 81 & 102 & 119 & 69 & 212 \\
\hline 2014 & 152 & 68 & 69 & 101 & 106 & 69 & 235 \\
\hline 2015 & 145 & 70 & 74 & 120 & 108 & 64 & 218 \\
\hline 2016 & 149 & 83 & 81 & 99 & 106 & 53 & 183 \\
\hline 2017 & 160 & 76 & 77 & 86 & 104 & 68 & 238 \\
\hline 2018 & 154 & 83 & 92 & 88 & 129 & 72 & 205 \\
\hline Av. & 149 & 75 & 79 & 99 & 112 & 66 & 215 \\
\hline Ranks & 6 & 2 & 3 & 4 & 5 & 1 & 7 \\
\hline
\end{tabular}

Source: Inventory days calculated from the financial statement available on the websites of the concerned companies

Table 3 explains the inventory days and relative ranking of the selected leading Indian pharmaceutical companies in India. As per the inventory days ranks, Cadila (66 days), Sun (79 days), and Lupin (75 days) companies manufacturing or production efficiency is better than the Glenmark (215 days), DR. Reddy's, (149 days), Cipla (99 days), and Aurbindo (112 days).

\subsubsection{Accounts Receivables days}

In the calculation of $\mathrm{CCC}$, Accounts receivables days refer to the days of collection of the amount of credit sales from the customers. The lower accounts receivables days refer to the efficiency or strategy of collection from the debtors or account receivables.

\section{Table 4}

Accounts Receivables days in Indian Pharmaceuticals Companies (2013-18)

\begin{tabular}{|c|c|c|c|c|c|c|c|}
\hline Years & DR & LU & $\mathrm{SU}$ & $\mathrm{CI}$ & AR & $\mathrm{CA}$ & GL \\
\hline 2013 & 90 & 82 & 75 & 72 & 99 & 55 & 119 \\
\hline 2014 & 86 & 78 & 48 & 57 & 118 & 57 & 131 \\
\hline 2015 & 95 & 74 & 67 & 64 & 83 & 67 & 140 \\
\hline 2016 & 99 & 115 & 86 & 61 & 80 & 62 & 120 \\
\hline 2017 & 96 & 89 & 82 & 61 & 66 & 86 & 95 \\
\hline 2018 & 102 & 119 & 104 & 67 & 68 & 97 & 93 \\
\hline Av & 95 & 93 & 77 & 64 & 86 & 70 & 116 \\
\hline Rank & 6 & 5 & 3 & 1 & 4 & 2 & 7 \\
\hline
\end{tabular}

Source: Accounts receivables days calculated from the financial statement available on the websites of the concerned companies 
Table 4 explains the accounts receivables days and relative ranking of the selected leading Indian pharmaceutical companies in India. As per days of accounts receivables ranks, Cipla (64 days), Cadila (70 days), and Sun (77 days) and Aurbindo (86 days) companies collection strategy from the accounts receivables is better than Glenmark (116days), DR. Reddy's, (95 days), and Lupin (93 days).

\subsubsection{Accounts Payables days}

In the calculation of CCC, Accounts payables days refer to the days of payment to the accounts payables or suppliers who supply the raw material or other inputs for the manufacturing or production process on credit. The higher accounts payables days refer to the effectiveness of the strategy of payment to the creditors or accounts payables.

\section{Table 5}

Accounts Payables days in Indian Pharmaceuticals Companies (2013-18)

\begin{tabular}{|c|c|c|c|c|c|c|c|}
\hline Years & DR & LU & $\mathrm{SU}$ & $\mathrm{CI}$ & $\mathrm{AR}$ & $\mathrm{CA}$ & GL \\
\hline 2013 & 70 & 84 & 33 & 36 & 60 & 37 & 75 \\
\hline 2014 & 50 & 73 & 29 & 34 & 61 & 46 & 83 \\
\hline 2015 & 42 & 94 & 43 & 50 & 61 & 46 & 108 \\
\hline 2016 & 55 & 99 & 44 & 38 & 66 & 49 & 93 \\
\hline 2017 & 51 & 98 & 50 & 39 & 52 & 58 & 69 \\
\hline 2018 & 62 & 120 & 64 & 46 & 58 & 57 & 74 \\
\hline Av. & 55 & 95 & 44 & 40 & 59 & 49 & 84 \\
\hline Ranks & 4 & 1 & 6 & 7 & 3 & 5 & 2 \\
\hline
\end{tabular}

Source: Accounts receivables days calculated the financial statement available on the websites of the concerned companies

Table 5 explains the accounts receivables days and relative ranking of the selected leading Indian pharmaceutical companies in India. As per accounts receivables days ranks, Lupin (95 days), Glenmark (84 days), Aurobindo (59 days), and Dr. Reddy's (55 days) companies' payment strategy is better than Cipla (40 days), Sun (44 days) and Cipla (40 days).

\subsubsection{Cash conversion cycle (CCC)}

The CCC is the period that considers the inventory days and accounts receivables days subtracting the accounts payables days. The lower cash conversion days reflects the manufacturing efficiency, effectiveness of the collection strategy from the accounts receivables, and payment policies of the business organization.

Table 6

Average Cash conversion cycle (CCC) days and Ranks of selected leading Indian pharmaceutical companies (2013-18)

\begin{tabular}{|c|c|c|c|c|c|c|c|c|c|c|c|c|c|c|}
\hline \multirow[t]{2}{*}{ Days } & \multicolumn{2}{|c|}{ DR } & \multicolumn{2}{|c|}{ LU } & \multicolumn{2}{|c|}{$\mathrm{SU}$} & \multicolumn{2}{|c|}{$\mathrm{CI}$} & \multicolumn{2}{|c|}{ AR } & \multicolumn{2}{|c|}{$\mathrm{CA}$} & \multicolumn{2}{|c|}{ GL } \\
\hline & Days & $\mathrm{R}_{1}$ & Days & $\mathrm{R}_{2}$ & Days & $\mathrm{R}_{3}$ & Days & $\mathrm{R}_{4}$ & Days & $\mathrm{R}_{5}$ & Days & $\mathrm{R}_{6}$ & Days & $\mathrm{R}_{7}$ \\
\hline Inventory Days & 149 & 6 & 75 & 2 & 79 & 3 & 99 & 4 & 112 & 5 & 66 & 1 & 215 & 7 \\
\hline Account receivable Days & 95 & 6 & 93 & 5 & 77 & 3 & 64 & 1 & 86 & 4 & 70 & 2 & 116 & 7 \\
\hline Account payable days & 55 & 4 & 95 & 1 & 44 & 6 & 40 & 7 & 59 & 3 & 49 & 5 & 84 & 2 \\
\hline Cash Conversion cycle days & 189 & & 73 & & 112 & & 123 & & 139 & & 87 & & 247 & \\
\hline CCC-Ranks & 6 & & 1 & & 3 & & 4 & & 5 & & 2 & & 7 & \\
\hline
\end{tabular}

Source: Based on calculation of table 3,4 , and 5

Table 6 reveals that Lupin (73 days), Cadila (87 days), Sun (112 days) companies' CCC reflect manufacturing efficiency, the effectiveness of the collection strategy from the accounts receivables and payment policies to the accounts payables. Glenmark (247 days), Dr. Reddy's (189 days), Aurbindo (139 days), and Cipla (123 days) companies' CCC reveal the negativity of the manufacturing, collection, and payment strategy of selected pharmaceutical companies. The ranks of inventory days, accounts receivable days, and accounts payable days of all selected leading Indian pharmaceutical companies reflect the negativity between the manufacturing efficiency, effectiveness of collection strategy, and payment strategy to the accounts payables. The selected Indian pharmaceutical companies who have better manufacturing efficiency and collection policies their payment strategies to the accounts payables are poor, comparatively.

\subsection{Size determinants and Cash Conversion Cycle (CCC) analysis}

The relational co-movement of the proxies of size determinants of the firms (TA, WC, and sales) and components of CCC (inventory days, accounts receivables days, accounts payables days) explain the relationship between the size and the SCF or the governance of the size determinants on the CCC components of the business organization. So, the systematic study of the relationship between size determinants and components of CCC can be divided into three categories.

\subsubsection{Relational co-movement of Size and Inventory days}

The relational co-movement of the size determinants' ranks and inventory days' ranks explains the impact of size proxies on the manufacturing efficiency. 
Table 7

Firms' size determinants and Inventory days relational co-movement

\begin{tabular}{|c|c|c|c|c|c|c|c|}
\hline Indian Pharm. Companies & $\mathrm{R}_{1}$ & $\mathrm{R}_{2}$ & $\mathrm{R}_{3}$ & $\mathrm{R}_{4}$ & $\mathrm{D}_{1}^{2}=\left(\mathrm{R}_{1}-\mathrm{R}_{4}\right)$ & $\mathrm{D}_{2}^{2}=\left(\mathrm{R}_{2}-\mathrm{R}_{4}\right)$ & $\mathrm{D}_{3}^{2}=\left(\mathrm{R}_{3}-\mathrm{R}_{4}\right)$ \\
\hline DR & 2 & 4 & 2 & 6 & 16 & 4 & 16 \\
\hline LU & 3 & 2 & 3 & 2 & 1 & 0 & 1 \\
\hline SU & 1 & 1 & 1 & 3 & 4 & 2 & 4 \\
\hline $\mathrm{CI}$ & 4 & 3 & 4 & 4 & 0 & 1 & 0 \\
\hline AR & 5 & 5 & 5 & 5 & 0 & 0 & 0 \\
\hline CA & 6 & 7 & 6 & 1 & 25 & 36 & 25 \\
\hline GL & 7 & 6 & 7 & 7 & 0 & 1 & 0 \\
\hline
\end{tabular}

Source: Ranks based on calculation of table $2\left(\mathrm{R}_{1}=\mathrm{TA}, \mathrm{R}_{2}=\mathrm{WC}, \mathrm{R}_{3}=\right.$ Sales) and table 3 ( $\mathrm{R}_{4}=$ Inventory days)

$$
\begin{array}{llll}
\mathrm{r}_{\mathrm{s}, 1.4}=1-\frac{6 * \sum(D * D)}{n(n * n-1)} ; & 1-\frac{6 * \sum(46)}{7(7 * 7-1)} ; & 1-\frac{276}{336}= & 0.18 \\
\mathrm{r}_{\mathrm{s}, 2.4}=1-\frac{6 * \sum(D * D)}{n(n * n-1)} ; & 1-\frac{6 * \sum(44)}{7(7 * 7-1)} ; & 1-\frac{264}{336}= & 0.21 \\
\mathrm{r}_{\mathrm{s}, 1.4}=1-\frac{6 * \sum(D * D)}{n(n * n-1)} ; & 1-\frac{6 * \sum(46)}{7(7 * 7-1)} ; & 1-\frac{276}{336}= & 0.18
\end{array}
$$

From Table 7, co-relational movement of size determinants proxies' ranks and inventory days' ranks explain that there is a low degree positive relationship between the size determinants and manufacturing efficiency in the Indian pharmaceutical companies. TA and sales revenue similarly governs the inventory days positively lower than the WC.

\subsubsection{Relational co-movement of Size and Account receivable days}

The relational co-movement of the size determinants' ranks and accounts receivables days' ranks explains the impact of size proxies on the collection efficiency of the business organization.

\begin{tabular}{|c|c|c|c|c|c|c|c|}
\hline Indian Pharm. Companies & $\mathrm{R}_{1}$ & $\mathrm{R}_{2}$ & $\mathrm{R}_{3}$ & $\mathrm{R}_{4}$ & $\mathrm{D}_{1}^{2}=\left(\mathrm{R}_{1}-\mathrm{R}_{4}\right)$ & $\mathrm{D}_{2}^{2}=\left(\mathrm{R}_{2}-\mathrm{R}_{4}\right)$ & $\mathrm{D}_{3}{ }^{2}=\left(\mathrm{R}_{3}-\mathrm{R}_{4}\right)$ \\
\hline DR & 2 & 4 & 2 & 6 & 16 & 4 & 16 \\
\hline LU & 3 & 2 & 3 & 5 & 4 & 9 & 4 \\
\hline SU & 1 & 1 & 1 & 3 & 4 & 4 & 4 \\
\hline CI & 4 & 3 & 4 & 1 & 9 & 4 & 9 \\
\hline $\mathrm{AR}$ & 5 & 5 & 5 & 4 & 1 & 1 & 1 \\
\hline CA & 6 & 7 & 6 & 2 & 16 & 25 & 16 \\
\hline GL & 7 & 6 & 7 & 7 & 0 & 1 & 0 \\
\hline & & & & \multicolumn{2}{|c|}{$\Sigma \mathrm{D}_{1}^{2}=50$} & $\Sigma \mathrm{D}_{2}{ }^{2}=48$ & $\Sigma \mathrm{D}_{3}^{2}=50$ \\
\hline
\end{tabular}

\section{Table 8}

Firms' size determinants and Accounts receivables days relational co-movement

Source: Ranks based on calculation of Table $2\left(\mathrm{R}_{1}=\mathrm{TA}, \mathrm{R}_{2}=\mathrm{WC}, \mathrm{R}_{3}=\right.$ Sales) and table 3 ( $\mathrm{R}_{4}=$ Accounts receivables days)

$$
\begin{array}{lll}
\mathrm{r}_{\mathrm{s}, 1.4}=1-\frac{6 * \sum(D * D)}{n(n * n-1)} ; & 1-\frac{6 * \sum(50)}{7(7 * 7-1)} ; & 1-\frac{300}{336}=0.11 \\
\mathrm{r}_{\mathrm{s}, 2.4}=1-\frac{6 * \sum(D * D)}{n(n * n-1)} ; & 1-\frac{6 * \sum(48)}{7(7 * 7-1)} ; & 1-\frac{264}{336}=0.04 \\
\mathrm{r}_{\mathrm{s}, 3.4}=1-\frac{6 * \sum(D * D)}{n(n * n-1)} ; & 1-\frac{6 * \sum(50)}{7(7 * 7-1)} ; & 1-\frac{300}{336}=0.11
\end{array}
$$

From Table 8, the co-relational movement of size determinants proxies' ranks' and accounts receivables days' ranks explain that there is a very low degree positive relationship between the size determinants and the collection efficiency in the Indian pharmaceutical companies. TA and sales revenue similarly govern the accounts receivables days positively more than the WC.

\subsubsection{Relational co-movement of Size and account receivable days}

The relational co-movement of the size determinants' ranks and accounts payables days' ranks explains the impact of size proxies on the payment strategy of the business organization. 


\section{Table 9}

Firms' size determinants and Accounts payables days relational co-movement

\begin{tabular}{|c|c|c|c|c|c|c|c|}
\hline Indian Pharm. Companies & $\mathrm{R}_{1}$ & $\mathrm{R}_{2}$ & $\mathrm{R}_{3}$ & $\mathrm{R}_{4}$ & $\mathrm{D}_{1}^{2}=\left(\mathrm{R}_{1}-\mathrm{R}_{4}\right)$ & $\mathrm{D}_{2}^{2}=\left(\mathrm{R}_{2}-\mathrm{R}_{4}\right)$ & $\mathrm{D}_{3}^{2}=\left(\mathrm{R}_{3}-\mathrm{R}_{4}\right)$ \\
\hline DR & 2 & 4 & 2 & 4 & 4 & 0 & 4 \\
\hline LU & 3 & 2 & 3 & 1 & 4 & 1 & 4 \\
\hline SU & 1 & 1 & 1 & 6 & 25 & 25 & 25 \\
\hline CI & 4 & 3 & 4 & 7 & 9 & 16 & 9 \\
\hline $\mathrm{AR}$ & 5 & 5 & 5 & 3 & 4 & 4 & 4 \\
\hline $\mathrm{CA}$ & 6 & 7 & 6 & 5 & 1 & 4 & 1 \\
\hline GL & 7 & 6 & 7 & 2 & 25 & 16 & 25 \\
\hline
\end{tabular}

Source: Ranks based on calculation of Table $2\left(\mathrm{R}_{1}=\mathrm{TA}, \mathrm{R}_{2}=\mathrm{WC}, \mathrm{R}_{3}=\right.$ Sales $)$ and table $3\left(\mathrm{R}_{4}=\right.$ Accounts payables days)

$\mathrm{r}_{\mathrm{s}, 1.4}=1-\frac{6 * \sum(D * D)}{n(n * n-1)} ; \quad 1-\frac{6 * \sum(72)}{7(7 * 7-1)} ; \quad 1-\frac{432}{336}=-0.29$

$\mathrm{r}_{\mathrm{s}, 2.4}=1-\frac{6 * \sum(D * D)}{n(n * n-1)} ; \quad 1-\frac{6 * \sum(66)}{7(7 * 7-1)} ; \quad 1-\frac{396}{336}=-0.18$

$\mathrm{r}_{\mathrm{s}, 3.4}=1-\frac{6 * \sum(D * D)}{n(n * n-1)} ; \quad 1-\frac{6 * \sum(72)}{7(7 * 7-1)} ; \quad 1-\frac{432}{336}=-0.29$

From Table 9, co-relational movement of size determinants proxies' ranks and accounts payables days' ranks, explain that there is a low degree negative relationship between the size of the firm and payment strategy of the Indian pharmaceutical companies. TA and sales revenue similarly govern the accounts receivables days negatively lower than the WC.

\subsubsection{Summary of relational co-movement $\left(r_{s}\right)$ of firm's size determinants and CCC components}

The summary of relational co-movement $\left(\mathrm{r}_{\mathrm{s}}\right)$ of the firm's size determinants and CCC components explains the comparative relationship of size and CCC.

Table 10

Summary of relational co-movement $\left(\mathrm{r}_{\mathrm{s}}\right)$ of firm's size determinants and CCC components

\begin{tabular}{|c|c|c|c|}
\hline \multirow[t]{2}{*}{ Size determinants } & \multicolumn{3}{|c|}{ Components of Cash conversion cycle (CCC) } \\
\hline & Inventory days & Accounts Receivables days & Accounts payables days \\
\hline TA & 0.18 & 0.11 & -0.29 \\
\hline WC & 0.21 & 0.04 & -0.18 \\
\hline Sales & 0.18 & 0.11 & -0.29 \\
\hline
\end{tabular}

Source: based on Table 7,8 and 9

Table 10 explains that size determinants affect the inventory days and accounts receivables days positively but low degree while negatively and the low degree to accounts payables in Indian pharmaceutical companies. The positivity of the inventory days with the size determinants is more than the accounts receivables days.

\subsection{Composite relational co-movement of Size and supply chain finance (SCF)}

The relational co-movement of the size ranks and CCC day's ranks of the selected Indian pharmaceutical companies' reveals the governance of the performance of SCF by the size of the business organization.

Table 11

Relational co-movement of size and CCC

\begin{tabular}{|c|c|c|c|c|c|c|}
\hline Indian Pharm. Companies & Sum of Size Det. & R1 & CCC days & $\mathrm{R} 2$ & $\mathrm{D}$ & D2 \\
\hline DR & 367014 & 2.5 & 189 & 6 & -3.5 & 12.25 \\
\hline LU & 372778 & 2.5 & 73 & 1 & 1.5 & 2.25 \\
\hline SU & 836562 & 1 & 112 & 3 & -2 & 4 \\
\hline $\mathrm{CI}$ & 344575 & 4 & 123 & 4 & 0 & 0 \\
\hline $\mathrm{AR}$ & 279563 & 5 & 139 & 5 & 0 & 0 \\
\hline CA & 210540 & 6 & 87 & 2 & 4 & 16 \\
\hline \multirow[t]{2}{*}{ GL } & 189440 & 7 & 247 & 7 & 0 & 0 \\
\hline & & & & & & $\Sigma \mathrm{D} 2=34.50$ \\
\hline
\end{tabular}

Source: Sum of size det. from Table 2 and CCC days from Table 6

$\mathrm{r}_{\mathrm{s}, 1.2}=1-\frac{6 * \sum(D * D)}{n(n * n-1)} ; \quad 1-\frac{6 * \sum(34.50)}{7(7 * 7-1)} ; \quad 1-\frac{207}{336}=0.38$ 
Table 11 explains the composite governance of supply chain finance by the size of Indian pharmaceutical companies. There is positive but moderate relational co-movement between the size and the supply chain finance $\left(r_{s}=0.38\right)$.

\section{Discussion}

The ranks of inventory days, accounts receivable days, and accounts payable days of all selected leading Indian pharmaceutical companies reflect the negativity between the manufacturing efficiency, effectiveness of collection strategy, and payment strategy to the accounts payables. The selected Indian pharmaceutical companies who have better manufacturing efficiency and collection policies their payment strategies to the accounts payables are poor, comparatively. There is a low degree positive relationship between the size of the firm and manufacturing and collection efficiency while low degree and negative co-relational movement between the size of the firm and payment strategy of the Indian pharmaceutical companies. The WC of the selected Indian pharmaceutical strongly and positively governs SCF than the TA and sales revenue. Indian pharmaceutical companies can improve their CCC by focusing on WC. In current assets, the company has to consider the inventory and accounts receivables while accounts payable in current liabilities (Mangiaracina et al., 2016). Overall, size determinants positively govern the CCC or supply chain finance (Uyar, 2009).

\section{Conclusion}

Based on the above analysis it can be concluded that there is a negative co-relational movement between manufacturing efficiency, collection efficiency or strategy, and payment system or payment policies of the Indian pharmaceutical companies. The Indian pharmaceutical companies' who have the efficiency in manufacturing and collection form the accounts receivables needed to improve their payments strategy or system to enhance the SCF as it has the negative co-relational movement with the size determinants. The size determinants i.e. TA, WC, and sales revenue govern the CCC positively and moderately. However, WC governs CCC positively and strongly while total assets and sales revenue were lower than the WC. The co-relational movements of size determinants and CCC components also indicate the need of improvement of the payment system or policies to improve the SCF of the business organization. Hence, the suggested model to enhance the efficiency of SCF can be modified as per the findings of the study. The order of the firms' size determinants and the components of the CCC can be re-ordered as per their degree of contribution in the enhancement of the supply chain finance.
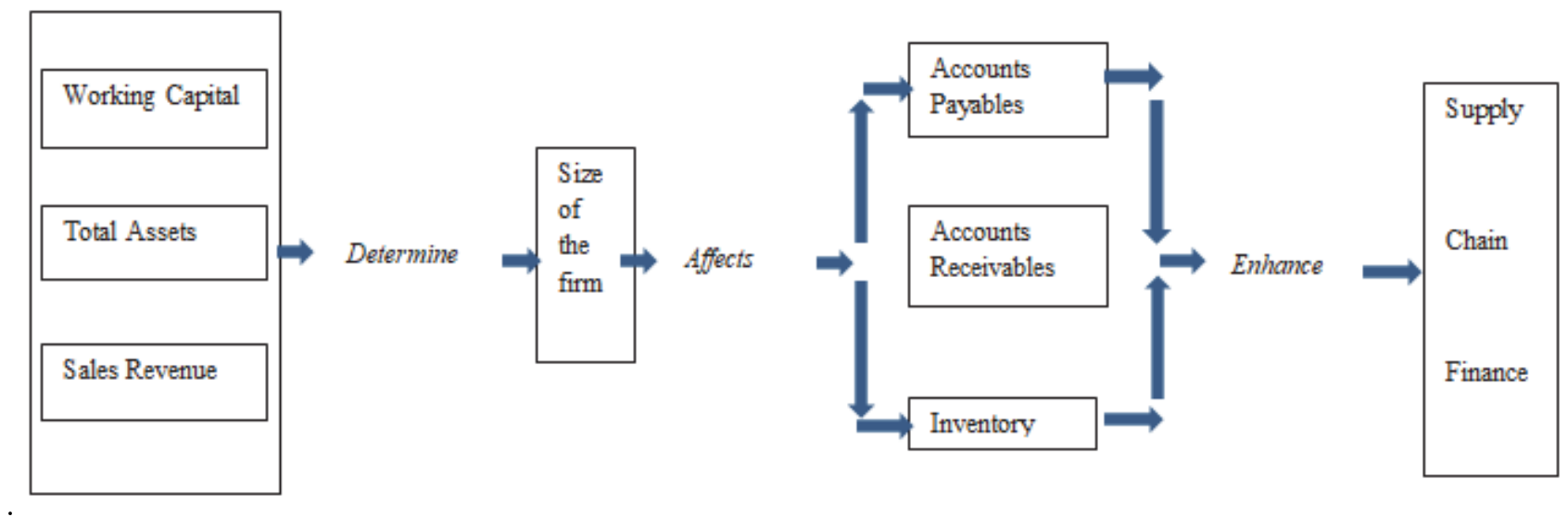

Fig. 3. Results of the research model

In Indian pharmaceutical companies, CCC can be shortened to enhance the SCF by focusing on size determinants and specifically on WC. The revision and change in the payment policy of the Indian pharmaceutical companies necessary to enhance the accounts receivables days. The present study considers only the data for a limited time (2013 to 2018) and quantitative financial variable. The frequency of CCC may be affected by some qualitative managerial factors. So, there is scope for further researches to study the relationship of size determinants and SCF by adding the related qualitative factors of the business organization.

\section{References}

Ali, A. (2020a). Do the giant players enjoy profitability?: Analytical study of Pharmaceutical Industry of India. Journal of Talent Development and Excellence, 12(2s), 3249-3260. 
Ali, A. (2020b). Does Size Affect Financial Performance?: Absolute and Relative Analysis of Materials Sector Companies of Saudi Arabia. Journal of Critical Reviews, 7(15), 212-220.

Ali, A. (2020c). Firm size and solvency in Indian pharmaceutical sector: A relational co-movement analysis. Accounting, 6(7), 1199-1208.

Balasubramanian, S., Shukla, V., \& Chanchaichujit, J. (2020).Firm size implications for environmental sustainability of supply chains: evidence from the UAE. Management of Environmental Quality, 31(5), 1375-1406. https://doi.org/10.1108/MEQ01-2020-0004

Bui, T. (2020a). How do financial leverage and supply chain finance influence firm performance? Evidence from construction sector. Uncertain Supply Chain Management, 8(2), 285-290.

Bui, T. (2020b). How does corporate performance affect supply chain finance? Evidence from logistics sector. Uncertain Supply Chain Management, 8(3), 563-568.

Bui, T. (2020c). Supply chain finance, financial development and profitability of real estate firms in Vietnam. Uncertain Supply Chain Management, 8(1), 37-42.

Bui, T., \& Doan, T. (2020). Factors influencing supply chain finance of real estate sector: Evidence using GMM estimation. Uncertain Supply Chain Management, 8(3), 627-632.

Chand, P., Thakkar, J. J., \& Ghosh, K. K. (2020). Analysis of supply chain performance metrics for Indian mining \& earthmoving equipment manufacturing companies using hybrid MCDM model. Resources Policy, 68, 101742.

Chen, X., Li, S., \& Wang, X. (2020). Evaluating the effects of quality regulations on the pharmaceutical supply chain. International Journal of Production Economics, 107770.

Cho, W., Ke, J. Y. F., \& Han, C. (2019). An empirical examination of the use of bargaining power and its impacts on supply chain financial performance. Journal of Purchasing and Supply Management, 25(4), 100550.

Doan, T., \& Bui, T. (2020). Nonlinear impact of supply chain finance on the performance of seafood firms: A case study from Vietnam. Uncertain Supply Chain Management, 8(2), 267-272.

Keown, A. J., Martin, J. D., Petty, J. W. and Scott, D. F. (2003). Foundations of Finance. $4^{\text {th }}$ ed., Pearson Education, New Jersey.

Lin, Q., \& Lin, X. (2020). Cash conversion cycle and aggregate stock returns. Journal of Financial Markets, 100560.

Maeenuddina, R. B., Hussain, A., Hafeez, M., Khan, M., \& Wahi, N. (2020). Economic Value Added Momentum \& Traditional Profitability Measures (ROA, ROE \& ROCE): A Comparative Study. TEST-Engineering and Management, 83, 13762 13774,

Mani, V., Jabbour, C. J. C., \& Mani, K. T. (2020). Supply chain social sustainability in small and medium manufacturing enterprises and firms' performance: Empirical evidence from an emerging Asian economy. International Journal of Production Economics, 227, 107656.

Phan, T., Doan, X., \& Nguyen, T. (2020). The impact of supply chain practices on performance through supply chain integration in textile and garment industry of Vietnam. Uncertain Supply Chain Management, 8(1), 175-186.

Upadhyay, S., \& Smith, D. G. (2020). Cash, Cash Conversion Cycle, Inventory and COVID-19. Journal of Health Care Finance, 46(4),37-44.

Uyar, A. (2009). The relationship of cash conversion cycle with firm size and profitability: an empirical investigation in Turkey. International Research Journal of Finance and Economics, 24(2), 186-193.

Wang, X., Lin, Y. and Shi, Y. (2020). Linking industrial agglomeration and manufacturers inventory performance: the moderating role of firm size and enterprise status in the supply chain. Journal of Manufacturing Technology Management. https://doi.org/10.1108/JMTM-11-2019-0417

Younis, H., \& Sundarakani, B. (2019). The impact of firm size, firm age and environmental management certification on the relationship between green supply chain practices and corporate performance. Benchmarking: An International Journal. 27(1), 319-346. https://doi.org/10.1108/BIJ-11-2018-0363

Zhou, H., \& Li, L. (2020). The impact of supply chain practices and quality management on firm performance: Evidence from China's small and medium manufacturing enterprises. International Journal of Production Economics, 107816.

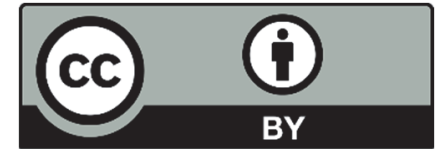

(C) 2020 by the authors; licensee Growing Science, Canada. This is an open access article distributed under the terms and conditions of the Creative Commons Attribution (CC-BY) license (http://creativecommons.org/licenses/by/4.0/). 